\title{
COVID-19 and its economic consequences for the Euro Area
}

\author{
Dirk Ehnts $^{1}$ (D) Michael Paetz ${ }^{2}$
}

Received: 6 July 2020 / Revised: 15 September 2020 / Accepted: 18 September 2020 /

Published online: 16 January 2021

(c) Eurasia Business and Economics Society 2021

\begin{abstract}
The coronavirus crisis reveals the shortcomings of the Euro Area (EA), which were already evident after the global financial crisis. We show that the self-imposed constraints within the EA have prevented a recovery in the last decade. However, the suspension of the stability and growth pact and recent measures of the European Central Bank have broken the chains. We recommend that national governments make use of their regained sovereignty inside the EMU framework and do not wait for European-wide solutions. In addition, we provide policy proposals consistent with the current EA framework.
\end{abstract}

Keywords Fiscal policy $\cdot$ Europe $\cdot$ Covid pandemic $\cdot$ Fiscal coordination

JEL Classification E42 $\cdot$ E62 $\cdot$ E65

\section{Introduction}

The economic consequences of the shutdown in response to the COVID-19 pandemic are difficult to predict. The IMF (2020) in its World Economic Outlook from June 2020 expects the greatest worldwide downturn since 1930 and forecasts a contraction of the advanced economies by $8 \%$. However, for the Euro Area (EA) the expected reduction in real GDP is even greater at about $10.2 \%$. Compared to the global financial crisis (GFC) 13 years ago, governments and central banks all over the world have reacted swiftly. Without these interventions, the world economy would probably have collapsed. Nevertheless, the short-run negative economic impact of the pandemic is already bigger than that of 2008/09.

Dirk Ehnts

dirk@ehnts.de

Michael Paetz

michael.paetz@uni-hamburg.de

1 TU Chemnitz, Chemnitz, Germany

2 Hamburg University, Hamburg, Germany 
It should be clear that a quick return to pre-COVID-19 policies in the EA would have devastating consequences for economic and political reasons. If governments would try to consolidate their budgets, as they did during the years after the financial crisis, a long-lasting depression is the most likely outcome. Yet, Southern European countries have already been in a bad economic shape before COVID-19. The unemployment rates in 2019 for Spain (14.1\%), Italy (10.0\%) and Greece (17.3\%) were in the double digits, with a recession in Germany looming at the end of the year. In Greece and Italy, real GDP per capita was still lower in 2019 than in 2007. If forced to return to austerity measures, they might prefer to leave the Euro. Austerity policy cannot be successful within the next few years for the same reason it has not been successful in the past decade: It exacerbates the economic downturn and the substantial fall in income increases both public deficits and debt-to-GDP ratios.

On a theoretical level, we recognize that unemployment is caused-ceteris paribus - by a lack of demand. Businesses are currently not constrained by the supply side, but by a general lack of spending. Over the medium term, the ECB $(2020,3)$ expects that "weaker demand will put downward pressure on inflation". In contrast to the European Commission and Roeger et al. (2019), which believe that output gap indicators perform well, we believe that the rate of unemployment is a better indicator to understand whether the economy is reaching its limits. Given the relatively high unemployment rates in some EA countries, we believe there are quite a lot of idle resources available, including labor.

We therefore recommend using the upcoming years to reconsider the macroeconomic policies in the EA. A Green New Deal (GND) including public employment would prevent a depression in the short-run and likewise improve the long-run economic prospects through a pioneering switch towards a sustainable production. Contrary to prevailing opinion, we do not believe that such policies are unavailable due to a lack of money. The pandemic causes painful real costs, in terms of losses in production and employment. However, the financial costs of the pandemic-losses in revenues of households, firms and the public sectorcan be neutralized by increases in government spending. Instead of aiming at low public debt ratios, governments should therefore spend whatever it takes to keep demand at a level that is consistent with full employment. As long as the European Central Bank (ECB) cooperates with national governments, higher public deficits will not have any negative impact in our current constitutional setupneither in the short nor in the long-run. On the contrary, cutting public spending would increase the real costs of the crisis and possibly feed right-wing anti-European forces (Funke et al. 2016).

The paper is organized as follows. In Sect. 2, we illustrate the economic development of the EA after 2008 and carefully sketch the expected difficulties of the upcoming years. This is a challenging task, since we have not seen anything comparable to the current situation. The subsequent section separates the real from the financial costs that will occur during and after the pandemic, before Sect. 4 discusses the special institutional framework within the EA. From the preceding analysis, we will be able to derive short-term recommendations that are feasible 

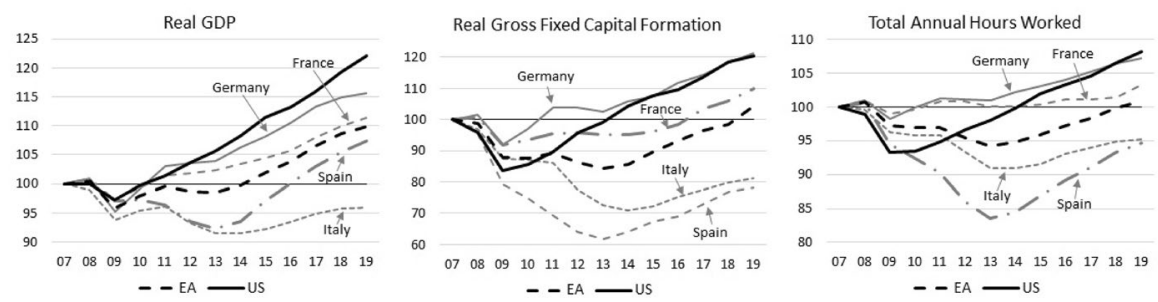

Source: Ameco. Note: $2007=100$

Fig. 1 Economic development in the EA and the US

within the current EA framework. In addition, we will present some mediumterm reform proposals. The final section concludes.

\section{The EA before and after the COVID-19 shock}

In what follows, we sketch the economic development of selected countries of the EA after the GFC. We form a comparison with other countries to illustrate the relatively slow and weak recovery of the EA. The point we want to make is that the EA recovery from the GFC has been partial at best. A comparison shows that other currency areas performed better, since their constitutional foundations allowed a more courageous intervention. Significant reforms of EA and EU institutions are needed to address this problem, which has now turned into a bigger problem. Furthermore, we carefully take a look on the most likely development after the pandemic.

\section{The EA development after the GFC}

The EA did never fully recover from the GFC, as Fig. 1 illustrates. Compared to 2007, real GDP increased by less than $10 \%$, and real gross capital formation as well as total hours worked have barely increased until today. Compared to the US, the recovery has been weak. In addition, the different member countries show very divergent dynamics during the recovery from the GFC: While Germany's growth rates have been relatively high, after being Europe's taillight beginning of the 1990s and the early 2000s, Italy has not yet fully recovered.

The figures also show that the EA faced a double dip recession, since even the gentle upswing has been interrupted by a second downturn after 2011. The reason for this has been the ECB's decision to raise the interest rate in 2011 following a recovery in oil prices. After an increase in real GDP of $1.9 \%$ on average in 2010 and 2011, real GDP fell again by $4.3 \%$ in 2012. In opposition, the interest-rate response of the US-FED after 2007 was faster, stronger and even longer than in the EA, as shown in the left panel of Fig. 2. 

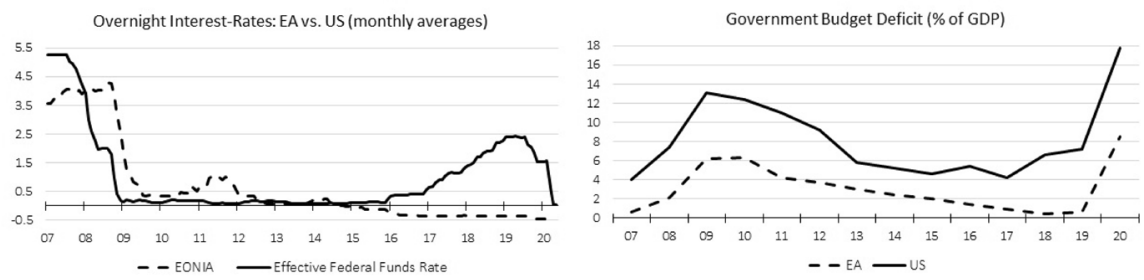

Source: FRED and Bundesbank.

Fig. 2 Macroeconomic policy after the GFC in the EA and the US

In addition, fiscal policy has also been more expansionary in the US. Public spending supports the US economy until today, while in the EA governments responded timidly and quickly switched to austerity measures. These different macroeconomic strategies explain the divergent developments in both currency areas shown above. Moreover, the much more aggressive US policy mix enabled the Fed to escape the zero interest-rate policy in 2017, while the overnight interest rate in the EA became negative in the same year and stayed there until today.

The preceding figures should be a warning signal to European policymakers. After such a substantial fall in economic activity, (more) expansionary monetary and fiscal policies need to stay for many years to support the recovery. The biggest mistake in the EA was the idea of fiscal consolidation in the middle of a global crisis (Papadimitriou and Wray 2012). As Godley (1992) recognized, cutting government spending in times of crisis with no availability of monetary policy or exchange rate policy leads to a process of cumulative decline. The consequence was a lost decade with low growth, high unemployment, and even rising debt ratios, as a collapsing GDP obviously ruins any attempt to balance government budgets. For example, Greece's consolidation efforts have been very ambitious, while the debtto-GDP ratio skyrocketed due to a fall of real GDP about one fourth. More desirable relative debt dynamics could have been achieved by expansionary fiscal policies at higher GDP and employment levels. Germany's chancellor, Angela Merkel, has said herself on June 4th, 2020, that "if we would do nothing [about fiscal policy], the [national] debt would be bigger". ${ }^{1}$ Moreover, expenditure cuts in Southern European countries often affected the health sector (Stuckler et al. 2017), thereby increasing the problems faced since the pandemic.

The main problem after a financial turbulence is that households and corporations are over-indebted and forced to reduce their spending to decrease the liabilities accumulated before the crisis. Figure 3 illustrates this by showing the change in the accumulation of financial assets and liabilities in selected EA countries. In Germany, this process already started with the burst of the New Economy bubble in 2001, while in Southern European countries the emergence of the real estate bubble overcompensated the Dot-Com crash until 2008. When firms and households reduce

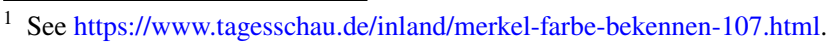



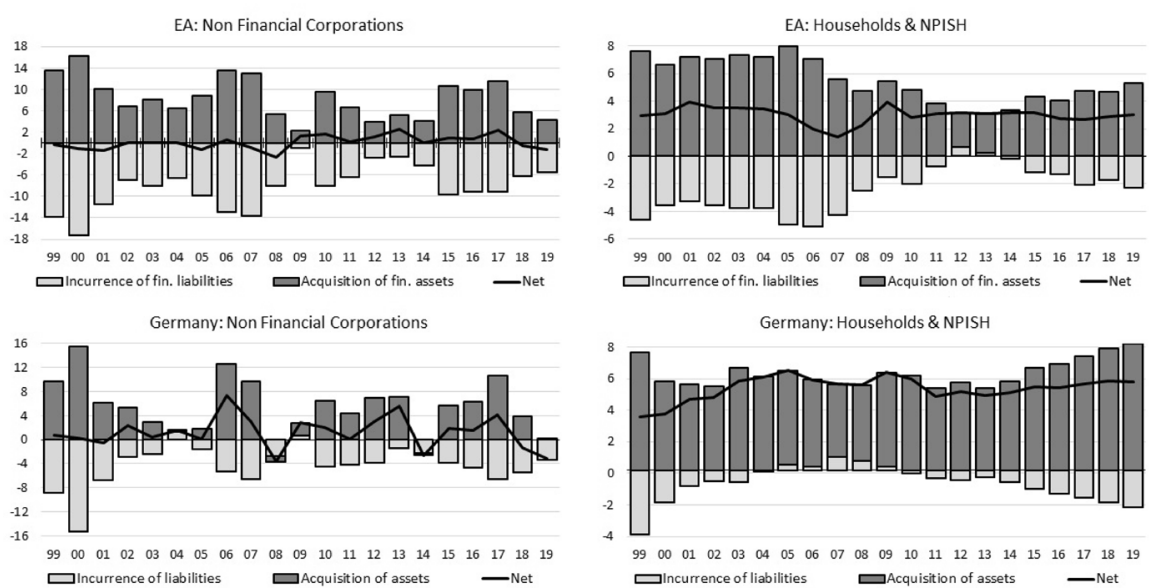

Germany: Households \& NPISH

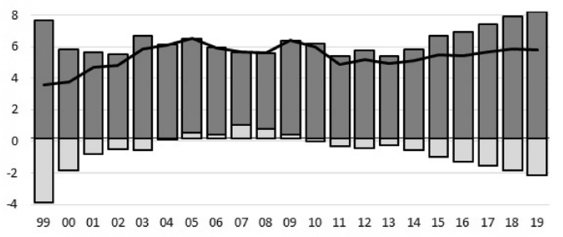

France: Non Financial Corporations

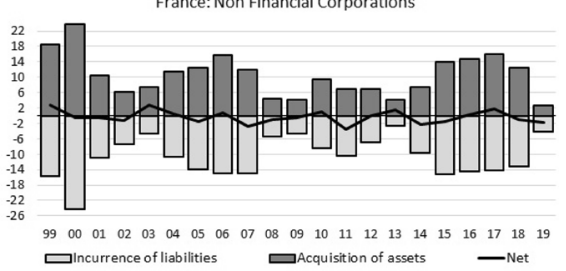
$\square$ Incurrence of liabilities $\square$ Acquisition of assets -Net

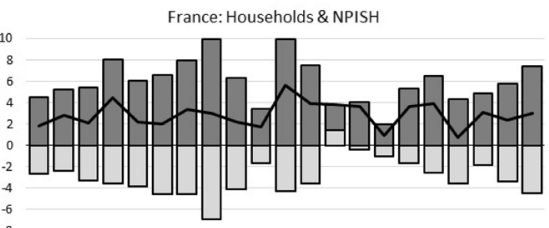

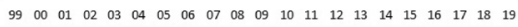
चincurrence of liabilities $\square$ Acquisition of assets —Net

Italy: Non Financial Corporations

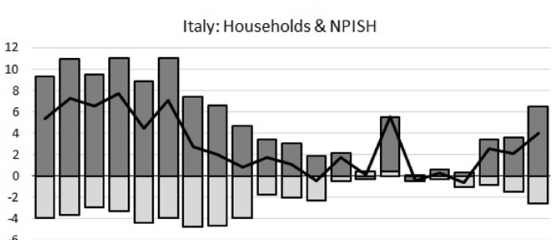

$\begin{array}{lllllllllllllllllllll}99 & 00 & 01 & 02 & 03 & 04 & 05 & 06 & 07 & 08 & 09 & 10 & 11 & 12 & 13 & 14 & 15 & 16 & 17 & 18 & 19\end{array}$ चincurrence of liabilities $\square$ Acquisition of assets -Net

Spain: Households \& NPISH
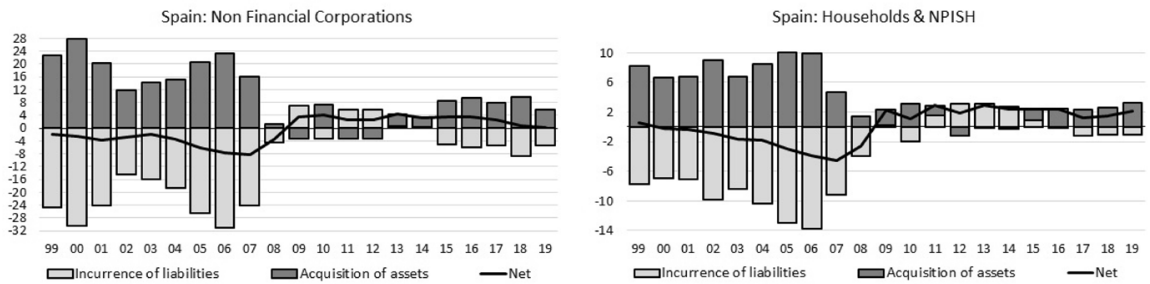

Source: Financial accounts, ECB.

Fig. 3 Accumulation of financial assets and liabilities in selected EA countries (\% of GDP), NPISH nonprofit institutions serving households

their spending, demand and production fall. A policy of fiscal consolidation obviously strengthens the downturn in such an environment and cannot be successful. As a consequence, almost all debt-to-GDP ratios in the EA have increased, despite the public efforts to reduce deficits (see for example Gechert and Rannenberg 2015). 
Table 1 Annualized growth rates of real GDP in selected industrial countries

\begin{tabular}{llllcrr}
\hline & $1981-1991$ & $1992-1998$ & $1999-2007$ & $2008-2013$ & $2014-2018$ & 2008-2018 \\
\hline EA & 2.92 & 1.94 & 3.15 & -0.39 & 2.15 & 0.79 \\
Germany & 3.16 & 1.30 & 2.32 & 0.59 & 2.05 & 1.39 \\
Greece & 1.21 & 2.40 & 5.85 & -5.26 & 0.70 & -2.36 \\
Spain & 3.71 & 2.62 & 5.81 & -1.71 & 3.17 & 0.45 \\
France & 2.77 & 1.94 & 3.27 & 0.42 & 1.58 & 0.96 \\
Italy & 2.57 & 1.52 & 1.85 & -1.52 & 1.15 & -0.33 \\
Portugal & 4.45 & 2.80 & 2.53 & -1.58 & 2.58 & 0.24 \\
Sweden & 2.23 & 2.61 & 4.91 & 1.05 & 2.99 & 2.11 \\
UK & 3.30 & 3.40 & 4.16 & 0.55 & 1.93 & 1.36 \\
Switzerland & 2.15 & 1.28 & 3.68 & 1.07 & 1.96 & 1.64 \\
Australia & 3.06 & 4.69 & 5.35 & 2.86 & 2.59 & 2.89 \\
Canada & 2.27 & 3.55 & 4.70 & 1.50 & 1.69 & 1.80 \\
New Zealand & 1.09 & 4.35 & 5.31 & 2.12 & 3.94 & 3.25 \\
US & 3.50 & 4.05 & 4.23 & 1.14 & 2.55 & 1.94 \\
\hline
\end{tabular}

Source: Authors' own calculations based on AMECO (macro-economic database of the European Commission)

Real GDP growth rate of the corresponding period divided by the number of years considered
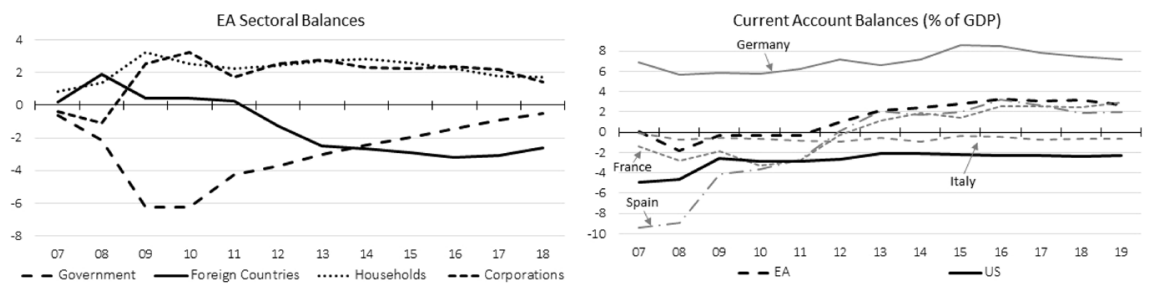

Source: Ameco.

Fig. 4 Sectoral balances and current accounts in the EA

However, the EA does not only perform poorly compared to the US, as the annualized growth rates of real GDP in Table 1 show. Among the listed industrial nations there is no other country that recorded negative growth rates on average in the five years after the GFC. It is hardly surprising that citizens in Southern Europe show no enthusiasm for the European project, considering that the growth rates of these countries have been much better before the introduction of the euro than they are today. Compared to the US even Germany is nothing more than the one-eyed among the blind. This clearly indicates that the current macroeconomic policy restrictions in the EA represent an obstacle to growth.

The reason for Germany's relative success is her extraordinary export surplus (see Fig. 4). Labor market reforms and weakened unions kept wages low after the introduction of the Euro. Unit labor costs and prices fell relative to other European 
countries and increased Germany's competitiveness (Flassbeck 2007; Flassbeck and Lapavitsas 2013) — at the cost of southern European countries that suffered from a lack of demand after the financial collapse suddenly stopped the rally at housing markets. Since average inflation in the EA was quite constant relative to the rest of the world, ${ }^{2}$ the Euro did not appreciate, as the D-Mark did before the introduction of the Euro, and Germany also gained competitiveness against non-EA members. Without the Euro this beggar-thy-neighbor policy would have been doomed to fail.

Obviously, such an export-driven recovery cannot be a role model for the big and rather closed EA, which mostly depends on domestic demand. However, before COVID-19, the EA seemed to follow this strategy, as the sectoral balances and the current accounts of selected EA member states in Fig. 4 illustrate. The return to budget consolidation has only been possible since foreign countries became the net debtors from the EA viewpoint. Yet, the positive current accounts of most EA countries are not a sign of increased competitiveness. Instead, the net export surpluses are the direct consequence of lower imports due to the weak recovery shown in Fig. 1. In addition, the interest rate differential on overnight money, illustrated in Fig. 2, weakens the euro and strengthens this development. This might be one intention of the ECB's strategy of negative interest rates.

The export surplus has caused international tensions over the last years. US president Trump, for example, criticized the EA several times and announced to impose tariffs on EA products. Hence, the mercantilist approach endangers the success in reducing trade barriers achieved over the last decades. From a balance sheet perspective, foreign countries need to increase government deficits to compensate the domestic demand, which they are losing to the EA. However, the US development demonstrates that a fast recovery does not depend on export surpluses. In addition, the global nature of the upcoming crisis will lead to a reduction in global demand and counteract any export-driven recovery. This effect might be amplified, if countries try to achieve a positive trade balance by cutting wages, thereby reducing effective demand and international trade further. ${ }^{3}$

Before we turn to the current situation, we like to note that the world economy (including the EA member states) already shown recessionary tendencies before the COVID-19 shock. Hence, for the EA the last decade can be summarized by a GFC with subsequent low but positive growth rates, which had already been turning to negative territory again before most countries finally recovered.

\subsection{Careful projections for the upcoming decade}

Conventional recessions exhibit some dynamics that unfold continuously: The economy slows down, investments decrease, unemployment rises, and as consequence, income and consumption expenditures fall. During this process, the slump

\footnotetext{
${ }^{2}$ According to Eurostat Data the average percentage change in the GDP deflator between 1999 and 2008 was roughly 1.99 in the EA, 2.33 in the US and 2.18 in the U.K.

${ }^{3}$ Original Mercantilists were aware of this "fallacy of cheapness" that could also turn the terms-of-trade against a country. See Keynes (1936), chapter 10.
} 
intensifies and monetary and fiscal policy should be used to counteract it. After a while, the economy starts to recover and improved expectations about the future increase investments, employment, production and consumption.

There are no such dynamics this time but a sudden and deep fall in expenditures. Nevertheless, some economists believe that we will observe a V-shaped recession with a similar sudden recovery. Since households would reduce their consumption expenditures solely due to missed opportunities when shops were closed, they would be able to increase their savings for some time and thus a strong catch-up effect would start during the recovery.

We believe this "catch-up theory" to be highly implausible. Many workers lost their jobs or at least a part of their income and corporations turned to increased bank borrowing to compensate for the loss of revenues. In Germany, short-time work allowances cover $60 \%$ to $87 \%$ of the income lost to workers. Eurozone unemployment has ticked upwards to $7.8 \%$ in June 2020 , an increase of only $0.1 \%$. However, the number will probably be revised upwards as by now it is clear that tourism in Mediterranean countries will be hit hard. Consequently, households and firms will come out of the crisis with a combination of lower savings and higher debt.

Even though reliable figures are only available with a time lag there are a number of indicators that already support this expectation. At the end of May, the Financial Times reported that US companies borrowed a trillion dollar in just 5 months, roughly as much as they usually do in a year. ${ }^{4}$ The German ifo Institute recently published a study according to which about one third of the companies surveyed are already negotiating with banks (Sauer and Wohlrabe 2020). OECD (2020) also expects a massive liquidity crisis in response to the confinement measures in most countries. Moreover, Reinders et al. (2020) illustrate that the increase in nonperforming loans due to COVID-19 poses a threat to the financial stability of the euro zone and might cause a banking crisis.

Hence, consumption and investment expenditures will be foregone and the situation might not be very different from the one described in Sect. 2.1. The risk of another double dip recession is very high, since the drop in production so far is (almost) exclusively due to the emergency measures in the wake of the pandemic. The usual decline in investment and consumer spending when a recession begins and expectations about the future development deteriorate is yet to come.

As we argued above, an export-driven strategy will be no possible answer to a global crisis. As households and firms all over the world will cut their expenditures and try to achieve a financial surplus, the governments are the only available spender of last resort that have to tolerate a net deficit. This is especially the case for the EA, where interest rates are already negative and monetary policy has no space left to increase private investments. ${ }^{5}$ The only chance to avoid a depression will be a strong and long-lasting fiscal response. Government demand would increase private

\footnotetext{
4 See https://www.ft.com/content/099099e7-615e-447d-a665-b3614d467dfa.

5 We do not believe that quantitative easing (QE) can contribute to a positive net effect for private investment, though it can be used to stabilize financial market prices in order to stop a collapse in private investment, as we shall describe in more detail below.
} 
sector profits and employment, so that the former will be able to pay down its debt or increase savings to pre-crisis levels, respectively.

\section{The nexus between a government and its central bank}

In the following, we explain why the lockdown causes painful real costs, while the financial costs are easy to cover for a sovereign currency area. Fiscal and monetary policy can lower the real costs of the crisis and reduce supply side effects to a minimum.

\subsection{Repeat after me: the costs of the crisis are real and present}

Economists, policy makers and the press are constantly writing about the financial costs of the crisis. This view of things is fundamentally wrong. Financial costs are actually a microeconomic concept at a firm-level. They describe the expenses for production factors in monetary units. However, without production there are no costs in this sense.

To put it bluntly, the real costs of the crisis are the sudden loss of production faced during the lockdown. This is the price we have to pay. It cannot be financed as it is already paid. The idea to distribute the costs of the corona crisis in a fair manner is therefore based on a misunderstanding. People already have consumed less and some lost a part of their incomes. Some production has not been undertaken and this real damage cannot be made up for.

Additional real costs may arise in the future if production capacities decrease. These real costs can at least partly be offset when increased government spending compensates for lower expenditures of the private sector. In this way, government spending maintains economic activity at a higher level of employment and public deficits allow the reduction of private debt. Hence, real costs would decrease if governments simply accept the deficits that are very likely to result in the next years, since less firms might go bankrupt and more workers keep their jobs. However, if we stick to the concept of financial costs, we might as well forget the matter. If governments want to finance additional spending through taxation, they would deprive citizens and companies of precisely the purchasing power that they want to inject.

\subsection{The difference between fiscal and monetary policy in a severe debt crisis}

Since conventional monetary policy is ineffective, in a debt crisis like the one described above, only public spending can fill the demand gap. As long as households and corporations use most of their revenues for paying down their debt, lower interest rates will not stimulate additional private expenditures. Monetary policy can only keep refinancing costs for the private sector low to support the process of debt relief. Moreover, the central bank has to stabilize asset prices, since creditors use financial assets as securities and might not be able to roll over existing credits, if asset prices fall. 
However, the central bank cannot directly increase aggregate demand and is thus unable to induce additional income. Monetary policy can be approximated by an asset swap, which does neither affect the net financial nor the real wealth of the private sector. Private banks simply swap reserve balances for securities with the central bank. ${ }^{6}$ On the other side, fiscal policy does not depend on the willingness of the private sector to borrow and invest. Government spending directly increases both financial and real wealth of the private sector. As long as the government can activate unused resources that exist because of private demand being too low, there is little reason for governments not to put them to work.

\subsection{How to pay for the crisis}

Higher public debt is also often rejected with two further arguments. Governments would need to repay their debt at some point and hence must align their expenditures with theirs in the long run. Moreover, government debt would burden future generations. These ideas again result from the microeconomic concept of financial costs. However, the question is not about money but about available resources. The central bank is always able to make payments on behalf of the government. It is not a technical issue.

In contrast to the private sector, governments do not spend from bank accounts in private banks, but only use their respective central bank. In doing so, the central bank, in cooperation with the banking system, generates deposits for the recipients' banks at the central bank's reserve accounts by keystroke. These deposits represent currency and are the highest form of "money". The central bank could, for example, just pay the bills of the government, as in past war times. During the COVID-19 pandemic, the Bank of England $(\mathrm{BoE})$ has announced an alternative measure that does not go all the way but comes close to a war time arrangement. It has agreed to mark up the Ways and Means account of HM Government.

The usual way to refill the government's main account at the BoE is the issuing and sale of government bonds. Technically, there is no difference between the central bank buying those bonds and private banks buying those bonds. The private banks probably have to borrow from the central bank in order to buy them. This, however, is a political choice and not part of the standard rules of a payment system. Currency used for fiscal policy operations always comes from the central bank. This statement also applies for the member states of EA.

Hence, the central bank must act as the lender of last resort for private banks and the government. There simply is no other source of currency. It can buy up existing government bonds and thus determine the price-and therefore the interest rates and yields - of government bonds. ${ }^{7}$ In doing so, it rejects from the outset any thought of the possible insolvency of a state. Investors can always sell their government bonds to the central bank at current prices. The central bank, which cannot run

\footnotetext{
${ }^{6}$ Banks do not and cannot lend out reserves to households and firms.

7 Borio et al. (2017) show that the historical development of long-term interest rates since 1870 is primarily driven by central bank policy.
} 


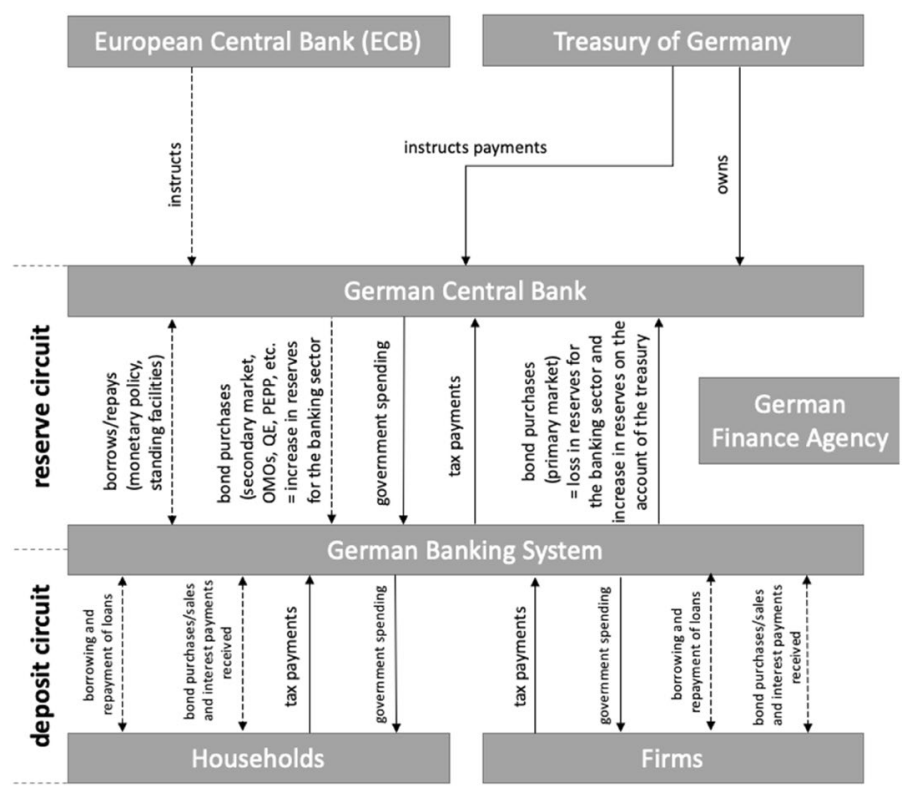

Source: own figure, based on Ehnts (2016).

Fig. 5 The fiscal-monetary nexus for Germany

out of money, effectively sets the risk of default to zero. This is no unconventional institutional setup, but one of the standard responsibilities of central banks in almost every currency union all over the world. In Canada, Switzerland, Sweden, Japan and China, for example, no investor would bet on an insolvency of the federal government. Before the introduction of the euro, national central banks also served as the lender of last resort for their national governments in the EA.

The nexus between a central bank, its government and the private sector works through two channels (Ehnts 2020). Figure 5 shows the full picture for the case of Germany (dashed lines for monetary operations, solid lines for fiscal operations). First, buying financial assets or granting credits to the banking system provides liquidity. If banks hold reserves at the central bank, they can get cash for it. This prevents potential bank runs. Banks can also transfer reserves more easily to other banks, which increases confidence within the banking sector. On the other hand, central banks clarify that governments do not have to worry about insolvency and can therefore spend whatever the outcome of the democratic process is.

Under this cooperative institutional arrangement, the state is the creator of currency and simply cannot run out of money. Its central bank is a fiscal agent of the government and manages the payment system of private banks, the federal government and other state agencies. These reserve accounts work like an Excel spreadsheet on which only the central bank can change entries according to its own rules. When the Federal Government pays, the central bank simply increases the balance of the receiving bank. 
Hence, all spending by the federal government creates new currency and new money (reserves and deposits). The currency flows back to the government when taxes are paid, while the deposits are deleted. The state merely promises to accept its own currency for tax payments in the future. The state cannot technically spend money that it has previously collected, just as a score of a football game does not come from numbers collected or saved in the past. The government spends by having the central bank increasing the accounts of the receiving banks. Decreasing the government's account prior to spending or after constitutes a political, not a technical operation. Hence the idea that governments pay expenditures with taxpayer money comes straight out of a fairy tale. During the Euro crisis, taxpayers saved neither the banking sector nor the Greeks. Newly created entries in the accounting system of central banks are the source of the hundreds of billions in payments to banks and governments during the GFC.

Therefore, as Ehnts and Paetz (2019) have argued, public debt is nothing more than the sum of tax credits owned by the private sector. They are a consequence of the public deficits of present and past. In this context, high national debt means high financial assets-which does not sound so unattractive for future generations. ${ }^{8}$ If the government wants to reduce public debt, it would continually have to collect tax revenues in excess of expenditures. Contrary to conventional interpretations, it is precisely the reduction of public debt that represents a burden on citizens while budget deficits add to the stock of private financial assets. Anyone who seriously wants to reduce government debt to zero has to explain who is going to pay the oneoff special taxes and how this will not lead to massive unemployment and deflation. Obviously, a reduction in public debt through higher tax payments means that citizens have less money at their disposal.

\subsection{Inflation is almost never a monetary phenomenon}

Another frequently raised objection to additional government spending claims that by increasing the money supply, additional spending would drive up the inflation rate. Figure 6 shows the development of government deficits and inflation rates in selected countries since the 1960s. During the 1970s with unemployment rates on historically low levels, high government deficits have indeed been accompanied by higher inflation rates. During this period, a number of special events coincided (collapse of the global fixed exchange rate system, oil price shocks and the Vietnam War). Since the 1980s, however, things have changed. Unemployment is the major problem of most advanced economies and inflation rates have been historically low-regardless of whether deficits have risen or fallen. National debt in Japan is now well over $200 \%$ of GDP, while inflation rates fluctuate around zero and the exchange rate is strong.

\footnotetext{
8 When interest rates are positive, government bonds generate unconditional income for the holders of the bonds. However, they are not the direct cause of inequality today, because interest rates have been falling since 1980 and in spite of this inequality has risen to record levels during this period. Nevertheless, falling interest rates may have indirectly caused rising inequality through asset price inflation (Bernoth et al. 2015).
} 


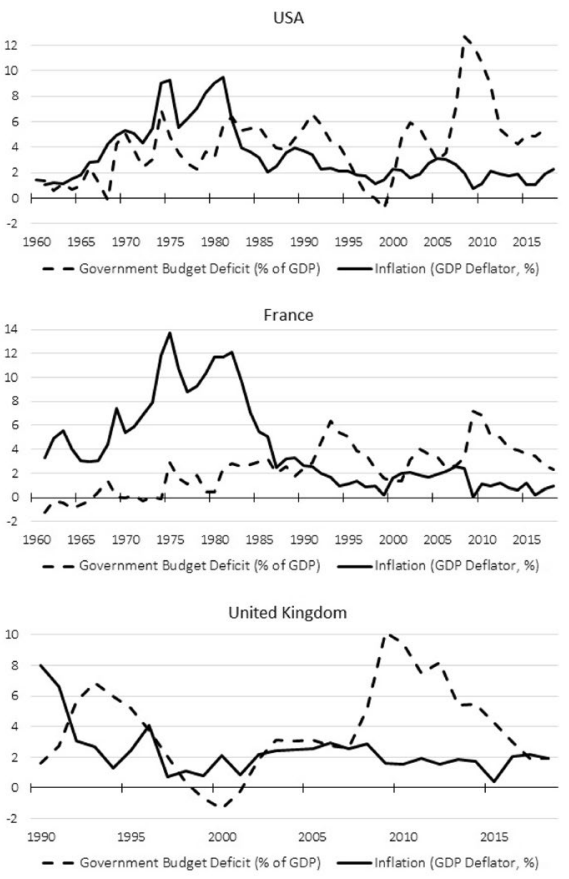

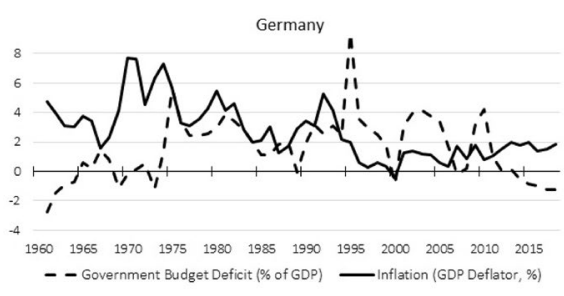

Italy
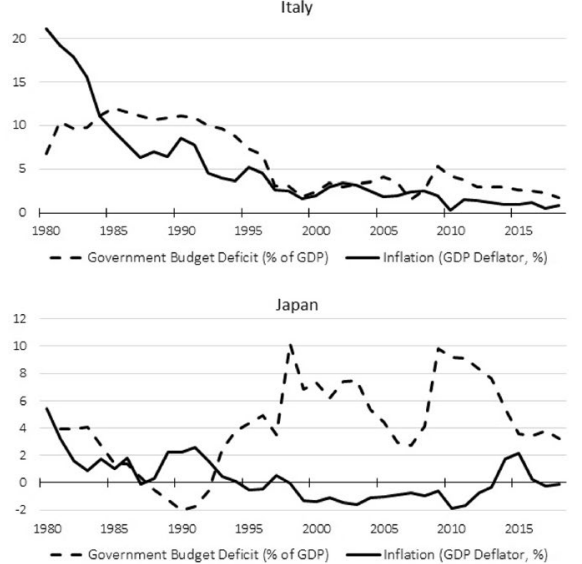

Source: Ameco, own calculations.

Fig. 6 Inflation rates and government deficits in selected countries

Keynes (1936) already explained that in a situation of underutilization quantities and not prices adjust to increased demand. Companies react to higher demand with an increase in output since their profits are positive and there is no scope for ramping up the price. ${ }^{9}$ Inflation does not depend on the money supply, but on the change in firms' average variable costs. At the macroeconomic level, these are unit labor costs and expenditures for imported inputs. If profit mark-ups and input prices are constant, prices do not increase as long as changes in nominal wages do not exceed productivity growth. ${ }^{10}$

Given the current underutilization of production facilities, higher demand will not put pressure on wages, so no increase in inflation should be expected. Firms need to increase wage payments to attract additional workers only when resources become scarce. ${ }^{11}$ It is very unlikely that this will happen within the next years due to the lack

\footnotetext{
9 See Helmedag (2016) for the finer points.

${ }^{10}$ The empirical literature confirming the assumption of mark up pricing for various decades and countries is overwhelming. See Lee (1999) and Downward (1999) for an overview or the empirical work on the US and the EA by Blinder et al (1998) or Fabiani et al (2006). Bobeica et al (2019) also come to this conclusion in an ECB working paper.

11 These prospects might also induce productivity-enhancing investments, increase available capacities and foster economic development.
} 
of demand described above. However, there could be a fall in available capacities if many firms go bankrupt during the pandemic. In this case, inflation rates could rise before employment reaches its pre-crisis level. For this reason, it is important that governments provide financial aid to the private sector and increase spending quickly to keep the real costs of the crisis as small as possible. If at some point the state and the private sector compete for scarce resources, a government must indeed decide to reduce expenditure or increase taxes in order to use additional resources for public purposes. However, if it keeps its deficit low in anticipatory obedience, this point will never be reached. Hence, low interest rates on government bonds are also in line with the central bank's mandate to keep inflation at some target level, since high unemployment rates would cause falling inflation rates or even deflationary tendencies via weakening nominal wage growth.

Nonetheless, some politicians are already trying to convert the supposed financial costs of coping with the coronavirus crisis into political reforms that will further push back welfare states and impose additional tax burdens on the working population. This neoliberal policy would increase the real costs of the pandemic by creating and sustaining involuntary unemployment.

\section{A closer look at the EA}

Apart from the technical facts described above, there are political rules that might prevent governments from spending whatever is needed. Many central banks are only allowed to carry out payments of the federal government when its account covers the amount to be paid. In practical terms, this means that the government issues additional government bonds whenever its expenditures exceed its tax revenues. The requirement that government spending needs to be covered by reserve balances at the central bank limits the possibilities of a sovereign government, but does not change the technical process described above.

In the EA, the political rules are particularly problematic, since the currency union consists of 19 member states sharing one currency, but do not have a European treasury that could cooperate with the ECB. In addition, the stability and growth pact (SGP) and the No-Bail out clause limit the space for national governments to increase spending in the case of a fall of private demand. From a monetary perspective, all of the 19 member states borrow money in a foreign currency, as the ECB is a supranational institution that is not responsible for national needs.

There is no other currency area where the hands of the governments are so tied by institutional constraints like in the EA. Yet, this unique experiment already failed during the GFC, since financial markets missed the case of Greece and reduced the ratings of government bonds far too late. As a result, falling prices of government bonds in the crisis countries caused both high interest rates and holes in bank balance sheets. Both exacerbated the crisis before austerity policies forced the member 
states to make further cuts in government spending. The consequence was the weak and divergent recovery illustrated in Sect. 2. Under existing rules EA member states do face a risk of insolvency and are thus unable to respond adequately to a severe crisis.

However, we will argue that the suspension of the SGP in combination with the measures taken by the ECB after the outbreak of COVID-19 has set member states back to their status as sovereign currency issuers that can do whatever is necessary. Moreover, we believe that such a national response is much more realistic under current conditions than a tedious discussion about Corona or Euro bonds that would lead to serious political problems within the EA. However, the ad-hoc changes of the rules show that the EA is built on shaky grounds. Hence, in the medium term there is the need for a comprehensive reform of the EA macroeconomic policy framework.

\subsection{The response to the COVID-19 shock in the EA: the rules of the game are changing}

Up to now, Germany has repeatedly stressed the ban on (direct and indirect) state financing by the ECB and the 3\% limit for government deficits. Since Wolfgang Schäuble, the black zero has ruled in the Berlin of the Grand Coalition. While some associate it with dilapidated infrastructure, lack of state innovation and investment, others claim it would be sound budgetary policy. This is why citizens expected little from the economic policy of the German-dominated European Commission when the coronavirus crisis hit the economy.

On March 20, 2020, EU Commission President Ursula von der Leyen announced the suspension of the SGP with its rigid 3\% deficit rule by activating the general escape clause, paving the way for national spending plans. According to the Commission President, her move means that EA member states can pump "as much liquidity as necessary" into the economy. The new president of the ECB, Christine Lagarde, started to put the brakes on, as she initially tried to distance herself from Mario Draghi's "whatever it takes". The ECB would not be responsible for the different interest spreads on newly issued government bonds of EA member countries.

As a result, investors expected Italy to leave the euro and Italian interest rate premiums shot up. Italy was threatened to become the new Greece. The ECB immediately announced that Lagarde's statements had been misinterpreted and that it would launch a $€ 750$ billion bond purchase program. The Pandemic Emergency Purchase Program (PEPP) increases bond prices and drives interest rates down, so that governments can borrow additional currency at a low price. As explained above, the ECB creates this currency by keystroke. Taxpayers do not finance government expenditures. $^{12}$

The so-called "issuer limit", which forbids the ECB to buy more than $33 \%$ of a country's bonds, has also been reconsidered. It was originally intended to allay

\footnotetext{
12 The former chairman of the US Federal Reserve, Ben Bernanke, confirmed this in an interview with the program “60 min”. See twitter.com/StephanieKelton/status/1238199214057959424.
} 
fears that the ECB was carrying out indirect monetary public financing. The ECB is now speculating that it would also abolish this limit: "To the extent that some self-imposed limits might hamper action that the ECB is required to take in order to fulfil its mandate, the Governing Council will consider revising them to the extent necessary to make its action proportionate to the risks that we face." With such a reform the ECB sends an important signal, because it could guarantee the solvency of all governments in the Eurozone. On June 4th 2020, the PEPP was expanded by an additional $€ 600$ bn.

On April 24 Italy decided to increase government spending by 55 billion euros. The interest rate on Italian government bonds with a term of 10 years fell from 1.99 to $1.87 \%$ on that day and currently (June 24 th) stands at $1.33 \%$. Italy has already rejected money from the European Stability Mechanism (ESM), which was established in the course of the last financial crisis and whose loans were tied to conditionality. The ESM is extremely unpopular in Italy and is perceived as an "instrument of fiscal torture". However, given the measures taken by the ECB and the Commission, the Italian government will neither run out of money nor be punished for excessive deficits.

\subsection{Possibilities within the existing EA framework}

The Corona crisis is just the beginning of a non-ideological understanding of the monetary system that, for the moment, is giving back monetary sovereignty to the EA countries. This allows a number of short- to medium-run policies within the existing EA framework.

When citizens or institutional investors buy government bonds, they simply exchange money for fixed-interest securities. When these government bonds mature, the central bank ensures that the government can pay back the money. The idea that the ECB should assume its role as a lender of last resort, thereby taking the determination of long-term interest rates away from financial markets, is the most important lesson of the Euro crisis we have analyzed in Sect. 2.

The imposition of austerity policy and the hair cut on public debt in Greece were mistakes that should best be avoided. Most countries within the EA have still not recovered in terms of GDP per capita. Hence, the ECB should ensure the solvency of the EA countries by signalling to investors that in the event of a crisis the ECB will buy their government bonds and thus make them risk-free. As we argued above, this is rather a normalization with respect to the EA than an unconventional institutional arrangement.

For now, national governments are able to increase their spending if needed. A European solution is therefore neither necessary nor sensible in the short-run. The important question for the long term will be what happens after the crisis. The PEPP can probably not be rolled back without raising the yields and subsequently interest rates of some euro countries. We would observe diverging interest rates: high where the crisis is and low where the economy is growing strongly. Increasing debt ratios as consequence of a crisis would force national governments to borrow from the ESM and accept conditionality. This would lead to a pro-cyclical fiscal policy. 
In this case, the euro crisis would return and consolidation measures would again prevent a recovery.

Given the mandate to stabilize the EA inflation rate, the ECB simply cannot implement such a recipe for European disaster, as this would also lead to deflationary tendencies (at least in some member states if not on average). Hence, PEPP needs to become a permanent feature. For as long as the EA has no Euro bonds, it should be part of the ECB's mandate to equalize the interest rates of government bonds across Europe. This would help the ECB to conduct their monetary policy operations centered on a single set of overnight interest rates.

What is needed instead of austerity measures are economic stimulus packages to rebuild the European economy. It makes sense to focus policy on the issues of climate change, inequality, the welfare state and public purpose and not, as in the wake of the GFC, to promote socially undesirable products with a cash for clunkers program. Hence, the SGP and the Maastricht treaty need to be reformed. Deficit criteria and target debt ratios have turned out to be no feasible economic indicators for inflationary pressures. In addition, the influence of a national government on deficits and debt-to-GDP ratios is very limited. Cutting expenditure will lead to less demand, less production and, via lower tax income, increase deficits. The major part of these deficits is endogenously determined by circumstances that lie out of the influence of national governments. As long as the ECB secures government bonds, there is no risk of insolvency. Instead of using public deficits in the context of the NAIRU (nonaccelerating inflation rate of unemployment) approach to curb government spending the SGP should use more appropriate indicators, like the actual rate of unemployment. Governments would be free to increase spending until their economy reaches full employment.

National governments would thus be able to ensure full employment by spending more on production and creating more employment (Ehnts and Höfgen 2019). This can be seen quite clearly in the case of short-time work benefits. Here the state pays an income for which the recipients do not even work. Why then should the state not create jobs for those who have lost their jobs not because of the coronavirus crisis, but because of a continuing weakness in demand? The fact that there are more job seekers than jobs is not the fault of the unemployed. Furthermore, we cannot save up labor. Those who do not work this year will not be able to take up two full-time jobs next year. Therefore, it makes sense for the state to base its spending on unemployment figures. Only when the economy gets closer to its full capacity level price stability might slowly come under threat.

The problem in the EA is that some governments may not follow this logic as long as existing deficit rules are only suspended but not modified. For example, the Spanish government was planning to cut public wages by $2 \% .{ }^{13}$ The money saved from these salary cuts was to be used for unemployment benefits, because the government expects higher unemployment in the near future. Here, a government accepts an increase in unemployment and refuses to support those affected. Instead of spending more, government employees and unemployed people are played off

$\overline{13}$ See https://www.larazon.es/economia/20200324/bxfi63qbfrhyteegwecqokfgae.html. 
against each other. Such economic policy measures are due to the current EA rules and follow the prevailing ideology of the Swabian housewife. Given these rules, we will most likely observe a further increase in inequality and divergence in the economic development between and within countries after the crisis. Italy, Spain and Greece would fall further behind without increased government spending, unemployment would rise significantly and social tensions would increase.

Regarding the conventional side of monetary policy, the ECB should increase its overnight rate to zero. Negative interest rates on reserves do not induce any additional investments. Given the huge amount of excess reserves in the banking sector, negative interest rates represent costs and might even lead to rising interest rates on entrepreneurial loans. According to Baldo et al. (2017), excess reserves are concentrated at around $80-90 \%$ of the total in a small number of EA countries, mainly Germany, France, the Netherlands, Finland and Luxembourg. Banks all over Europe already increased their accounting fees and some demand interest on customer's deposits that exceed a specific height. Hence, negative interest rates lower the private purchasing power and destabilize the banking sector.

Yet, there are two consequences of negative interest rates which might have positive effects on the EA development. Firstly, the euro exchange rate might depreciate and boost European exports. Secondly, banks are willing to buy government bonds at rates below zero, in order to reduce their reserve balances with the ECB. As we have argued above, an export-driven strategy will not be successful and increase international tensions. Moreover, government bonds are risk-free anyway if the ECB is willing to buy them. Hence, the ECB should increase its deposit rate to zero and relieve the burden from the EA banking system.

\subsection{It is still a long way to the United States of Europe}

There are also some political efforts to develop the EA into a United States of Europe. This would include a European ministry of finance (Euro Treasury), which issues Eurobonds. The ECB would be able to buy these without limit, similar to national government bonds with the PEPP, and would thus ensure that these bonds are always risk-free. This would result in the crowning glory of the EU, the transition from a supranational authority dependent on allocations from member states to a real government with its own source of money.

However, such a coronation in the middle of the biggest crisis since the 1930s, without a public discussion of the question whether such a construct is even desired by the population, would confront us with problems of democratic theory. The basic principles of articles 1 and 20 of the German basic law (Grundgesetz) for example, are "eternal". To what extent can Germany be a democratic and social country $(\$ 20)$ if its government spending is de facto limited by European rules? During times of crises the spending of the European Commission would rise while the spending of the German government would fall. This shift in power would at some point lead to constitutional conflict. Moving towards a Euro Treasury would cause a previously unknown loss of national competence and need to be discussed publicly. 
Moreover, given the current situation, it seems to be very unlikely that such a process would be successful. Over the last decade, we observed a return to nationalism in most EA countries and a discussion about a further loss of national competence might foster this development. The current debates on Eurobonds and the enlargement of the European budget show where the front lines are. In Northern European countries, citizens fear to be paying the debt of the southern EA member states, while citizens in the South still suffer from austerity and feel that they are not being treated with solidarity.

It would be much more promising to change the SGP and the Maastricht Treaty first. This could lead to comprehensive national investment programs and lower unemployment. A common mission, like a GND as proposed by Adler and Wargan (2019) could also bring back enthusiasm for the European project. The EA would reconstruct its industrial base and create millions of additional and sustainable jobs. Moreover, if citizens realize that there is neither a liability nor a solidarity issue with respect to government bonds when these are risk-free, the acceptance of a common government might increase. ${ }^{14}$

Another related common project would be a federal job guarantee (JG), which can also be realized within the current EA framework. Cruz Hidalgo et al. (2019) explain how a Euro Treasury might pay for a European JG. Given that monetary policy is not available, the big question of economic policy is about democratic control. Who will determine how much money will be spent and on what? Usually, parliaments and governments ensure that majority rules determine fiscal policy. Since such institutions do not exist at the European level, at least not in their proper form, a Euro Treasury would face a problem of legitimacy. Tying the Euro Treasury to the JG only would solve this problem. The only expenditures that the Euro Treasury would be allowed to execute would be those connected to the JG.

The JG is located at the local level and offers a job to everyone willing and able to work. Workers receive a living wage and social security will be supplied at the appropriate national level. This will lead to a crowding out of jobs that do not pay a living wage, which should not exist in the first place since they are either directly or indirectly subsidized by the government or other parts of society. The JG does not cover existing or future public sector jobs. The idea is to use the JG as a buffer stock so that instead of being unemployed the workers not used in the public and private sector remain in employment. This will have large positive effects on social life and the approval of the European project.

The JG also solves the macroeconomic dilemma of the EA. Since the creation of the Euro, government spending has been too low. We need a more expansionary fiscal policy. At the national level, this is not forthcoming. With politicians embracing long disproven theories like that of (expansionary) austerity and balanced budgets, it seems to be hopeless to expect national governments to somehow coordinate and achieve just the right level of government spending that is consistent with full employment. Since the unemployment caused by this threatens to destroy the

\footnotetext{
14 Mazzucato and Semieniuk (2017) show that such mission-based projects, which were carried out in cooperation between government and the private sector, have generated enormous innovation gains.
} 
political project of Europe it needs to be addressed. How much then should Brussels spend in order to reach full employment? The answer to that question is impossible to find. This is why the JG is such a valuable addition. It leads to full employment by automatically providing the needed increase in spending that is associated with full employment. Also, it stabilizes the economy since workers transit from normal jobs to the JG in bad times and vice versa in good times, reducing the change in income implied. The change from the JG to the private sector will also be eased as firms do not need to hire previously unemployed persons. In addition, the JG should be combined with qualification measures to avoid mismatch problems after the GND. Since unemployment will increase in the near future and governments do not bid-up private wages, there is no risk of increasing inflation rates.

It is important to note that the GND would be a supplement to public investment programs, not a substitute. It would help especially low-skilled workers who will suffer most from the upcoming economics crisis. Nonetheless, national governments should increase full-time public employment in sectors like education and health care to fill the gaps in public goods provision, which originated during the budget consolidation years after the GFC. Such strategies would also increase the approval for a common European project. Since many resources will be unused after the pandemic, now it might be the best time to implement such policies.

\section{Conclusions}

The preceding analysis illustrated that the institutional foundation of the EA has not been well prepared to respond to the GFC. The SGP, the Maastricht Treaty and the No-Bail out clause have created a neoliberal mind set among policy makers that tends to emphasize the view that government debt is inherently bad while no such stigma is put on private debt. This has led to policy choices in the wake of the GFC that, after a brief period of fiscal stimulus, forced the member state governments to cut expenditures. The resulting weak and divergent recovery is commonly known as the lost decade in Southern European countries.

The first responses to the coronavirus crisis suggest that the question "How do we pay for this?" has died. The activation of the general escape clause in the SGP together with the PEPP by the ECB has given national governments a green light to spend. Surprisingly, this issue has not been covered widely in the media or academic debates. To our knowledge, the only other publication apart from our own that covers this issue is a blog post by Claeys and Wolff (2020) from March 2020. There is some hope that policy makers within the EA learned their lessons and will not repeat the mistakes made after 2008. Given the lack of private demand that can be expected for the next few years, fiscal policies have to be more expansionary and the ECB will have to ensure the solvency of national governments.

We believe it to be very unlikely that the process to form the United States of Europe can be finished within the middle of the upcoming crisis. Therefore, we recommend that national governments should increase investments in the ecological 
reconstruction of its industrial base. For the moment, the ECB ensures solvency with its PEPP program and the rules of the SGP are suspended. Hence, there are no monetary limits on national expenditures. Since unemployment rates will increase later in 2020, there will be much room for higher investments and no pressure on inflation rates. Moreover, the ECB should raise its overnight interest target to zero to relieve the burden of the European banking system. A Job Guarantee could be an appropriate supplement to public investment programs if a political consensus for higher national government spending cannot be reached.

While in the short-run national governments are able to do whatever is necessary, there is the risk of a quick return to pre-crisis austerity policies that would lead to yet another lost European decade. Hence, European policy makers should use the next years to bring forward the following reform proposals:

1. Most importantly, government bonds need to be generally risk-free in the EA. The PEPP should be made permanent and the ECB should get a mandate to equalize interest rates on government bonds across EA member states and guarantee solvency of member state governments.

2. National governments should further increase their investments in the ecological reconstruction of its industrial base in the form of a GND. Adler and Wargan (2019) suggest using the EIB to channel the money towards national governments, which would have the advantage that current fiscal rules are not broken.

3. The SGP and the Maastricht Treaty need to be reformed. Increasing debt-to-GDP ratios are no problem, if the ECB secures the solvency of the EA member states. Moreover, deficits are not controlled by national governments and the existing rules bear the risk of a pro-cyclical fiscal policy. Instead, the size of national deficits should be replaced by measures of economic activity, for example, unemployment rates. As long as unemployment is high, national government expenditures should not be restricted.

The GND could be executed on a mission-based approach, addressing the younger generation of Europeans who suffered particularly strong after the GFC. We could hope to build up new enthusiasm for the European project. The important question for the next generation is about how to use the available resources to deal with problems of present and future. However, the question of state funding has been overcome, no matter if we want to fight climate change, eliminate unemployment or raise taxes to protect democracy from the power of the super-rich. ${ }^{15}$ It is time to gear the political system to our real problems instead of arbitrary figures like the government deficit or debt divided by the gross domestic product.

\footnotetext{
${ }^{15}$ See Saez and Zucman (2020) for a comprehensive analysis of the connection between taxes and inequality.
} 
Funding None.

\section{Compliance with ethical standards}

Conflict of interest The authors declare that they have no competing interests.

\section{References}

Adler, D., \& Wargan, P. (2019). Green New Deal for Europe. https://gndforeurope.com. Accessed 17 Aug 2020.

Ameco. https://ec.europa.eu/info/business-economy-euro/indicators-statistics/economic-databases/macro -economic-database-ameco/ameco-database_en. Accessed 15 July 2020.

Baldo, L., Hallinger, B., Helmus, C., Herrala, N., Martins, D., Mohing, F., Petroulakis, F., Resinek, M., Vergote, O., Usciati, B., \& Wang, Y. (2017). The distribution of excess liquidity in the Euro Area, ECB occasional paper series 200. https://www.ecb.europa.eu/pub/pdf/scpops/ecb.op200.en.pdf. Accessed 17 Aug 2020.

Bernoth, K., König, P. J., Beckers, B., \& FortiGrazzini, C. (2015). Quantitative easing-what are the side effects on income and wealth distribution: In-depth analysis, DIW Berlin: Politikberatungkompakt, No. 99, Deutsches Institut für Wirtschaftsforschung.

Blinder, A., Canetti, E., Lebow, D., \& Rudd, J. (1998). Asking about prices: A new approach to understanding price stickiness. New York: Russell Sage Foundation.

Bobeica, E., Ciccarelli, M., \& Vansteenkiste, I. (2019). The link between labor cost and price inflation in the euro area. European Central Bank Working Paper Series 2235.

Borio, C., Disyatat, P., Juselius, M., \& Rungcharoenkitkul, P. (2017). Why so low for so long? A longterm view of real interest rates, Bank for International Settlements. Working Papers 685.

Claeys, G., \& Wolff, G. (2020). COVID-19 Fiscal response: What are the options for the EU Council? https://www.bruegel.org/2020/03/esm-credit-lines-corona-bonds-euro-area-treasury-one-off-joint -expenditures-what-are-the-options-for-the-eu-council/. Accessed 29 June 2020.

Cruz Hidalgo, E., Ehnts, D., \& Tcherneva, P. (2019). Completing the Euro: The Euro Treasury and the job guarantee. Revista de EconomíaCrítica, 27, 100-111.

Downward, P. (1999). Pricing theory in post-Keynesian economics: A realist approach. Aldershot: Edward Elgar Publishing.

Ehnts, D., \& Höfgen, M. (2019). The job guarantee: Full employment. Price Stability and Social Progress, Society Register, 3(2), 49-65.

Ehnts, D., \& Paetz, M. (2019). Die modern monetary theory: Staatsschulden als Steuergutschriften, DIW Berlin: Vierteljahrshefte zur Wirtschaftsforschung 4/2019, S. 77-89, DeutschesInstitutfürWirtschaftsforschung, Berlin.

Ehnts, D. (2020). The fiscal-monetary nexus in Germany. IPE working paper 138/2020, https://www. econstor.eu/bitstream/10419/215899/1/1694969355.pdf. Accessed 17 Aug 2020.

European Central Bank. (2020). Economic bulletin. https://www.ecb.europa.eu/pub/pdf/ecbu/eb202005. en.pdf. Accessed 17 Aug 2020.

Fabiani, S., Druant, M., Hernando, I., Kwapil, C., Landau, B., Loupias, C., et al. (2006). What firms' surveys tell us about price-setting behavior in the Euro Area. International Journal of Central Banking, 2(3), 3-48.

Funke, M., Schularick, M., \& Trebesch, C. (2016). Going to the extremes: Politics after financial crises, 1870-2014. European Economic Review, 88, 227-260.

Flassbeck, H. (2007). Wage divergences in Euroland: Explosive in the making. In J. Bibow \& A. Terzi (Eds.), Euroland and the world economy: Global player or global drag? (pp. 43-52). Basingstoke: Palgrave Macmillan.

Flassbeck, H., \& Lapavitsas, C. (2013). The systemic crisis of the Euro: True causes and effective therapies. Rosa Luxemburg StiftungStudien.

Gechert, S., \& Rannenberg, A. (2015). The costs of Greece's fiscal consolidation. Quarterly Journal of Economic Research, 84, 47-59.

Godley, W. (1992). Maastricht and all that. London Review of Books, 14(19), 3-4. 
Helmedag, F. (2016). NurmehrStundenlohnoderauchwenigerArbeitsstunden? GewerkschaftsforderungenimWiderstreit. In H. Hagemann \& J. Kromphardt (Eds.), Keynes, Schumpeter und die Zukunft der entwickeltenkapitalistischenVolkswirtschaften (pp. 273-287). Marburg: Metropolis.

IMF. (2020). A crisis like no other, an uncertain recovery. IMF World Economic Outlook Update, June 2020.

Keynes, J. M. (1936). General theory of interest, employment, and money. London: Macmillan.

Lee, F. (1999). Post Keynesian price theory. Cambridge: Cambridge University Press.

Mazzucato, M., \& Semieniuk, G. (2017). Public financing of innovation: New questions. Oxford Review of Economic Policy, 33(1), 24-48.

OECD. (2020). Corporate sector vulnerabilities during the Covid-19 outbreak: Assessment and policy responses, OECD policy responses to coronavirus (COVID-19).

Papadimitriou, D. B., \& Wray, L. R. (2012). Fiddling in Euroland as the global meltdown nears, Levy Economics Institute Public Policy Brief. https://www.levyinstitute.org/publications/fiddling-in-eurol and-as-the-global-meltdown-nears. Accessed 17 Aug 2020.

Roeger, W., Mc Morrow, K., Hristov, A., \& Vandermeulen, V. (2019). Output gaps and cyclical indicators. European economy discussion paper 104, https://ec.europa.eu/info/sites/info/files/economyfinance/dp104_en.pdf. Accessed 17 Aug 2020.

Reinders, H. J., Schoenmaker, D., \& Van Dijk, M. A. (2020). Is COVID-19 a threat to financial stability in Europe? CEPR discussion paper no. DP14922.

Saez, E., \& Zucman, G. (2020). The triumph of injustice-taxes and inequality in the 21st century. New York: Norton and Company.

Sauer, S., \& Wohlrabe, K. (2020). Kreditverhandlungen und Liquidität von Unternehmenwährend der Corona-Pandemie, ifoSchnelldienst Digital, 1, Nr. 10, München: ifoInstitut.

Stuckler, D., Reeves, A., Loopstra, R., Karanikolos, M., \& McKee, M. (2017). Austerity and health: The impact in the UK and Europe. European Journal of Public Health, 27(4), 18-21.

Publisher's Note Springer Nature remains neutral with regard to jurisdictional claims in published maps and institutional affiliations. 